\title{
Autor fotográfico y obrero del progreso: notas sobre el trabajo de Christiano Junior en la Argentina
}

\author{
Verónica Tell*
}

\begin{abstract}
Resumo:
Este trabajo apunta a analizar algunos aspectos de la obra de Christiano Junior realizada en la Argentina, en particular en la ciudad y provincia de Buenos Aires, a fines de la década de 1870. El objetivo es trabajar a partir de dos líneas de análisis. Por un lado, se propone vincular esta obra con la idea del progreso que atraviesa el fin de siglo, los emprendimientos, las mentalidades y los relatos (fotografía incluida). Por otra parte, se analiza el trabajo de Junior a la luz del concepto de idea tout court en tanto parece concentrar la imagen del fotógrafo sobre sí mismo en relación con su actividad y su producción.
\end{abstract}

\section{Palabras clave:}

Fotografía, progreso, autor, siglo XIX, Argentina.

Por sus iniciativas artísticas, técnicas y comerciales el portugués Christiano Junior estuvo sin dudas entre los fotógrafos más destacados de la fotografía argentina y latinoamericana del siglo XIX. ${ }^{1}$ Nació en las islas Azores en 1832 y emigró a Brasil en 1855 y de allí a la Argentina en 1867 donde se desempeñó como fotógrafo hasta 1883. En este país participó de la Exposición Nacional de 1871, la Industrial de 1877 y la Continental de 1882, fue premiado por la Sociedad Científica Argentina, la exposición de Filadelfia de 1876 y la de París de 1878. También sacó fotografías de la segunda exposición realizada por la Sociedad Rural Argentina y a él se deben posiblemente asimismo aquellas de la primera. Como todos los fotógrafos comerciales de la época se desempeñó como retratista y su fama llevó a buena parte de la alta sociedad porteña y de diferentes localidades a posar en su estudio.

En 1876 Christiano Junior prologaba con las siguientes palabras el primero de los dos álbumes que llegaron a salir de lo que fue el emprendimiento fotográfico de mayor envergadura realizado en la Argentina hasta ese momento:

Deseoso de corresponder cual cumple á la benévola acogida que merecieron mis trabajos fotográficos al imparcial jurado de la Exposición Nacional de Córdoba en 1871 -he pensado

\footnotetext{
* Doctora en Artes (Universidad de Buenos Aires).

1 La obra de Christiano Junior (José Christiano de Freitas Henriques Junior (1832-1902)) en la Argentina ha recibido la concentrada atención de Abel Alexander y Luis Priamo (ver bibliografía). En 1878 Junior vendió su estudio -incluyendo todos los materiales y negativos- a Alejandro Witcomb. El archivo Witcomb pertenece actualmente al Archivo Gráfico de la Nación y en él se encuentran, sin distinción fehaciente, los negativos debidos a Junior. Si bien sólo las fotografías incluidas en los álbumes o las cartes de visite que llevan el nombre de Junior son de su indiscutible autoría, el hecho de que éstas sean placas al colodión húmedo favorece la atribución de otras realizadas con este mismo procedimiento.
} 
que nada convendría mejor á mi objeto que reunir en una serie de ilustraciones, todo aquello que de notable encierra este hermoso país- tanto en monumentos como en panoramas de su pintoresca y exuberante naturaleza. Mi plan es vasto, y cuando el esté completo, la República Argentina no tendrá una piedra ni un árbol histórico desde el Atlántico á los Andes, que no se haya sometido al foco vivificador de la cámara oscura. [...] Tiempo era en que los extraños, que visitan esta parte de la América del Sur, al regresar á sus lares, encontrasen en la populosa Buenos Aires, una galería donde los cuadros que la realidad ofreció ante sus ojos, pudieran transportarse con la facilidad de este álbum. ${ }^{2}$

El prólogo continuaba unas pocas frases e informaba que las imágenes estaban acompañadas por textos descriptivos escritos por Mariano Carranza y Ángel Pelliza. ${ }^{3}$ Esta era una novedad propuesta por Junior puesto que las fotografías de los álbumes confeccionados por sus contemporáneos contaban solamente con un breve título (la mayor parte de las veces sólo el nombre del lugar) que con frecuencia era impreso en el mismo negativo. Además, los volúmenes no solían ser todos idénticos sino que las imágenes entre unos y otros variaban siguiendo, seguramente, la selección y preferencias del comprador. ${ }^{4}$ El portugués ofrecía, en cambio, una edición con idénticas fotografías en todos los ejemplares y que, a página abierta, tenía a la derecha la imagen y a la izquierda el texto en cuatro idiomas. Estas descripciones históricas, según su propia formulación, eran el modo de hacer que edificios o plazas significaran más allá de su fisonomía y de lo que previamente supiera quien las mirara. Los comentarios describían características edilicias, datos históricos y también sociales ${ }^{5}$.

Explicitar en su prólogo los objetivos del emprendimiento fue la forma de destacar la originalidad y amplitud del mismo y, evidentemente, de promocionarlo. No sólo con aquellas líneas promovía su trabajo, sino que antes de arribar a cada nueva

2 Al año siguiente Junior editó un segundo álbum con otras 12 fotografías. Un ejemplar de cada uno se conserva en la Biblioteca Manuel Gálvez y otro par en la Fototeca "Benito Panunzi" de la Biblioteca Nacional. La Academia Nacional de la Historia tenía también unos ejemplares pero desaparecieron hace aproximadamente tres años.

3 En español, francés, inglés y alemán en el primer álbum. En el segundo álbum el italiano reemplazó al alemán y Junior explicaba el cambio. Cabe notar que ese mismo trío encaró otro emprendimiento a mediados de 1877 que consistía en la Galería biográfica argentina con textos por Carranza y Pelliza y edición de Junior, con retratos litográficos de distintas personalidades firmados por R. Albertazzi. El 12 de junio de 1877 publicitaban en el periódico La Nación la primera entrega.

4 Este tipo de orden y selección que quedaba en manos del comprador había sido propuesto de modo explícito, por ejemplo, por el fotógrafo Du Mesnil para su álbum Notoriedades del Río de la Plata de 1862. "Esta constará de pequeños retratos fotográficos que, acompañados de algunas páginas de notas biográficas, se irán librando sucesivamente á la circulación y expendiéndose separadamente á un precio módico. De esta manera cada persona podrá tomar libremente las entregas que fueren de su agrado, y formar con ellas un plutarco ilustrado de sus simpatías, o sea un álbum para faltriquera de retratos y pequeñas biografías encuadernando al gusto de cada uno..." (La Tribuna, 01 de enero de 1862). Aunque se distinga de las vistas puesto que las personalidades representadas eran susceptibles de generar simpatías o antipatías según las adscripciones políticas de los compradores, se percibe que era un modo de venta posible en la época.

5 Los que denomino datos sociales son, por ejemplo: "Estas mejoras [el plantar sauces en la ribera] han hecho tolerable el ingrato oficio de la lavandera, sometida al suplicio de permanecer arrodillada varias horas sobre las toscas de la playa para ganar un mezquino jornal." o "Las familias pobres, así que se retiran los pescadores, se proveen de aquel desecho, que contribuye á su alimento" (Fragmentos de textos correspondientes a las fotografías Escenas de la playa (grupo de lavanderas) y Escenas de la playa (la red), respectivamente). 
provincia o localidad tenía por práctica anunciar su llegada en los periódicos locales (ALEXANDER-PRIAMO, 2002, p. 28) Este aspecto propagandístico pone de relieve el espíritu comercial y claramente profesional de su desempeño y puede ser, también, una de las claves para interpretar la afirmación de Junior respecto de la desatención de sus predecesores hacia los signos del progreso. Pues el fotógrafo afirmaba en su prólogo:

Hasta hoy han cuidado poco los artistas de la Ilustración en sus Ilustraciones, presentando únicamente escenas del campo, donde solo se transparenta la vida rústica, prescindiendo de aquellos signos inequívocos del progreso, que elevan sus cúpulas arrogantes en el centro de las ciudades. (JUNIOR, 1876)

Puesto que en líneas previas Junior se refería a sus propias fotografías como ilustraciones, se puede asumir que aquellos a quienes se refería con "artistas de la ilustración" eran fotógrafos y tal vez sólo en segunda instancia apuntaran sus palabras a grabadores, litógrafos o pintores. Sin embargo, en su calidad de fotógrafo profesional instalado en Buenos Aires desde 1867, Junior debía conocer el trabajo de Esteban Gonnet y de Benito Panunzi, los primeros en realizar álbumes con vistas de la ciudad.

En relación con el trabajo de Esteban Gonnet una nota en La Tribuna informaba en 1864: "Un fotógrafo de Buenos Aires ha tenido la feliz idea de sacar las principales vistas de esta capital. Con ellas ha formado un precioso álbum digno de adornar cualquier biblioteca" ${ }^{6}$. La "feliz idea" indicaba que aquel proyecto era novedoso y, por otra parte, la lista de las vistas dada a continuación promocionaba el trabajo y el criterio de selección de Gonnet. En efecto, las suyas fueron de las primeras imágenes de Buenos Aires impresas en papel albuminado y sus álbumes Recuerdos de Buenos Ayres fueron -hasta donde se tenga noticias- los primeros. ${ }^{7}$ Pocos años más tarde, Benito Panunzi ofrecía una colección de vistas por entregas bajo el nombre de Album Panunzi ${ }^{8}$ y también produjo al menos dos álbumes.

6 La Tribuna, 26 de octubre de 1864. Citado en Alexander y Priamo, 2000. Sobre la mención del articulista de que el álbum era digno de adornar cualquier biblioteca, cabe notar que el ejemplar existente en la Fototeca "Benito Panunzi" de la Biblioteca Nacional lleva escrito a pluma: "Remitido por orden del SE el Señor Gobernador para que se conserve en la Biblioteca. Junio 30 de 1864" lo cual pone en evidencia que su valoración como objeto de importancia cultural fue inmediata. Esteban Gonnet era un francés radicado en Buenos Aires seguramente desde finales de la década del 50 y que falleció en esa ciudad en 1868 . Se le pudieron atribuir los álbumes y fotos -que sólo consignaban en una pequeña estampilla "Fotografía de Mayo 25 de mayo 25"- gracias a la referida nota de La Tribuna, que decía que en esa dirección se encontraba el establecimiento fotográfico de Gonnet. Por lo demás, no hay datos en las fotos ni publicidades en los periódicos que reúnan dirección del estudio y nombre del fotógrafo.

7 Alexander y Priamo (2000) señalan la existencia de un álbum anterior sobre la ciudad de Buenos Aires, realizado por James Niven hacia 1863, aunque éste estaba aparentemente destinado a un uso privado.

8 Así estaba anunciado en El Nacional del 7 de abril de 1868. Citado en Alexander y Priamo, 2000. Los autores destacan lo inusual de la venta por entregas de fotografías y señalan que hay en Leon Pallière -quien entre marzo de 1864 y febrero de 1865 vendió una colección de 52 litografías bajo el título Album Pallièreun antecedente que el italiano debió considerar prestigioso. Agrego a esto el primer antecedente francés del Album Photographique de l'artiste et de l'amateur publié sous la direction de M. Blanquart-Evrard, de 1851, que se vendía en entregas mensuales con tres láminas reproduciendo monumentos y obras arte acompañadas por una hoja con datos históricos y que podían ser reunidas en álbum al finalizar la colección. La noticia brindada por El Nacional es, según estos autores, la primera que se tiene de la actividad profesional de Panunzi quien, a diferencia de lo acostumbrado, no publicó anuncios en los periódicos. 
Según lo afirma Luis Priamo, "este italiano fue el primer fotógrafo que se propuso realizar una documentación amplia y sistemática de la ciudad. Este relevamiento analítico (visible en sus fotos de las plazas 25 de Mayo y de la Victoria o de la zona ribereña) se combinaba con el registro de los cambios producidos en el paisaje urbano." (PRIAMO, 1998, p. 58)

Así, ambos produjeron vistas de la ciudad y luego álbumes con ellas, pese a lo cual Junior afirmaba que sus predecesores se habían ocupado únicamente de escenas de campo. Temas que efectivamente los dos habían tratado de manera profusa aunque, como se ve, no exclusiva. En este sentido, es interesante notar que la séptima entrega del Album Panunzi estaba compuesta por una fotografía de la plaza del Parque y otra de pobladores del campo. Si la combinación de ambos temas podría ofrecer la posibilidad de vender ese conjunto a los interesados en sólo uno de ellos, analizado desde un lugar no exclusivamente comercial sino cultural más amplio, también podría implicar que el italiano no estuviera aplicando una distinción necesariamente dicotómica entre uno y otro sino que simplemente combinara en una entrega la realidad circundante, del mismo modo que unía ambos asuntos en el conjunto total. En este sentido, si el álbum litográfico de Pallière podría considerarse un antecedente del de Panunzi para la distribución por entregas podría serlo, también, en lo que concierne a la reunión de escenas urbanas y rurales en una misma carpeta. ${ }^{9}$ En este caso, pese a la diferencia técnica, habría un fuerte lazo con la tradición iconográfica previa y sus modos de distribución.

Todo esto podría dar la clave para interpretar las categóricas palabras de Junior no como una falsedad ni exclusivamente como una frase publicitaria sino como la expresión de un modo de ver la realidad que se presentaría, ahora sí, en dos categorías diferenciales. Es decir que en su percepción debió existir una franca contraposición entre la vida rústica y las cúpulas. Entre todas las imágenes que se han podido identificar como debidas a Junior sólo hay tres fotos de gauchos y criolla frente a sus ranchos y ninguna de tareas rurales (ALEXANDER-PRIAMO, 2002, p. 25). Sin embargo, considerando sobre todo el trabajo de Junior como fotógrafo de la segunda exposición rural organizada por la Sociedad Rural Argentina (aunque fuera retribuido económicamente y no debido a su propia iniciativa), conviene resituar la oposición rusticidad-progreso a la que se refería en el prólogo.

El mundo rural al que se acercaba Junior se estaba diferenciando fuertemente del de las décadas anteriores y, además, el lugar desde donde él se vinculaba se enraizaba en otras búsquedas y proyectos. Se desarrollaba contemporáneamente un proceso de transformación productiva $y$, en tanto se implementaban nuevas prácticas de producción, nuevas tecnologías e inversiones mayores, comenzaba a llevarse adelante una experiencia de tipo empresarial en la explotación agropecuaria. (zEBEIRo, 1999) En este sentido, hay que notar el hito que significó

9 El considerar el Album Pallière como antecedente del de Panunzi en relación con las entregas es una hipótesis de Alexander y Priamo (2000, p. 28). También son ellos quienes señalan que Pallière reunió en su séptima entrega El corral, Pita y ombú, Parada de la diligencia en la Pampa y Cazuela del teatro Colón, es decir, temas urbanos y rurales. ¿Por qué no considerar entonces esta conjunción de temas en Pallière también como un antecedente para la selección temática de Panunzi? 
la fundación de la Sociedad Rural Argentina en 1866. Ésta buscaba dar cohesión a una clase terrateniente y representar sus intereses en relación con el Estado y la elite política e impulsar el proceso de cambio tecnológico, es decir que pretendía definir con otras pautas las actividades rurales y la vinculación de la elite propietaria con ellas y orientar los progresos del sector. (HORA, 2002, p. 3) En relación con la Sociedad, señalamos que Junior no sólo fue fotógrafo de su segunda exposición, en 1876 (y presumiblemente también de la primera) sino que se había asociado en 1875. Por otro lado, su paso previo por el Brasil y sobre todo la experiencia de su participación en la Exposición Nacional de Río de Janeiro en 1866 y luego, en 1871, en la primera Exposición Nacional en la ciudad de Córdoba, en las que ganó sendas medallas, ${ }^{10}$ debieron incidir en esta perspectiva de Junior. El culto al progreso puesto en ejercicio en tales encuentros debió encontrar asidero en un fotógrafo profesional exigente e innovador como Junior. Además, si lo que podríamos llamar ampliamente lo rural se encontraba representado en estas exposiciones, no lo estaba como valor cultural (lo que podría relacionarse con la tradición iconográfica de las costumbres, los viejos modos de lo rural) sino en relación con los progresos en el sector agropecuario y su productividad. Así, una cosa son las escenas de campo (gauchos frente al rancho, pulperías, etc. que sus antecesores realizaron en gran número) y otra distinta, el Aberdeen Angus premiado por la Sociedad Rural. Entre ambas, la que Junior tomó fue siempre la opción por lo nuevo. O de otro modo, si conserváramos los términos rural y urbano tal como los plantean Altamirano y Sarlo para el caso de Esteban Etcheverría, cabría pensar que así como en su relato el matadero es un espacio de penetración de lo rural en lo urbano, en el caso de Junior las fotografías de animales premiados serían la penetración de lo urbano en lo rural. Si el par civilización-barbarie no está planteado explícitamente en sus palabras preliminares, rusticidad y progreso aparecen como términos más amables que señalan igualmente que para Junior la ciudad era un espacio cultural.

La primera de sus vistas urbanas, en la apertura del álbum, es elocuente respecto de esto. Junior inauguraba su serie con una panorámica de Buenos Aires tomada desde un ángulo infrecuente. [il. 1]

10 Junior fue premiado con medalla de bronce en Río de Janeiro y de oro en Córdoba, lo cual era una importante fuente de legitimación profesional que la elite ( $y$ también sus pares) debió reconocer y valorar. 


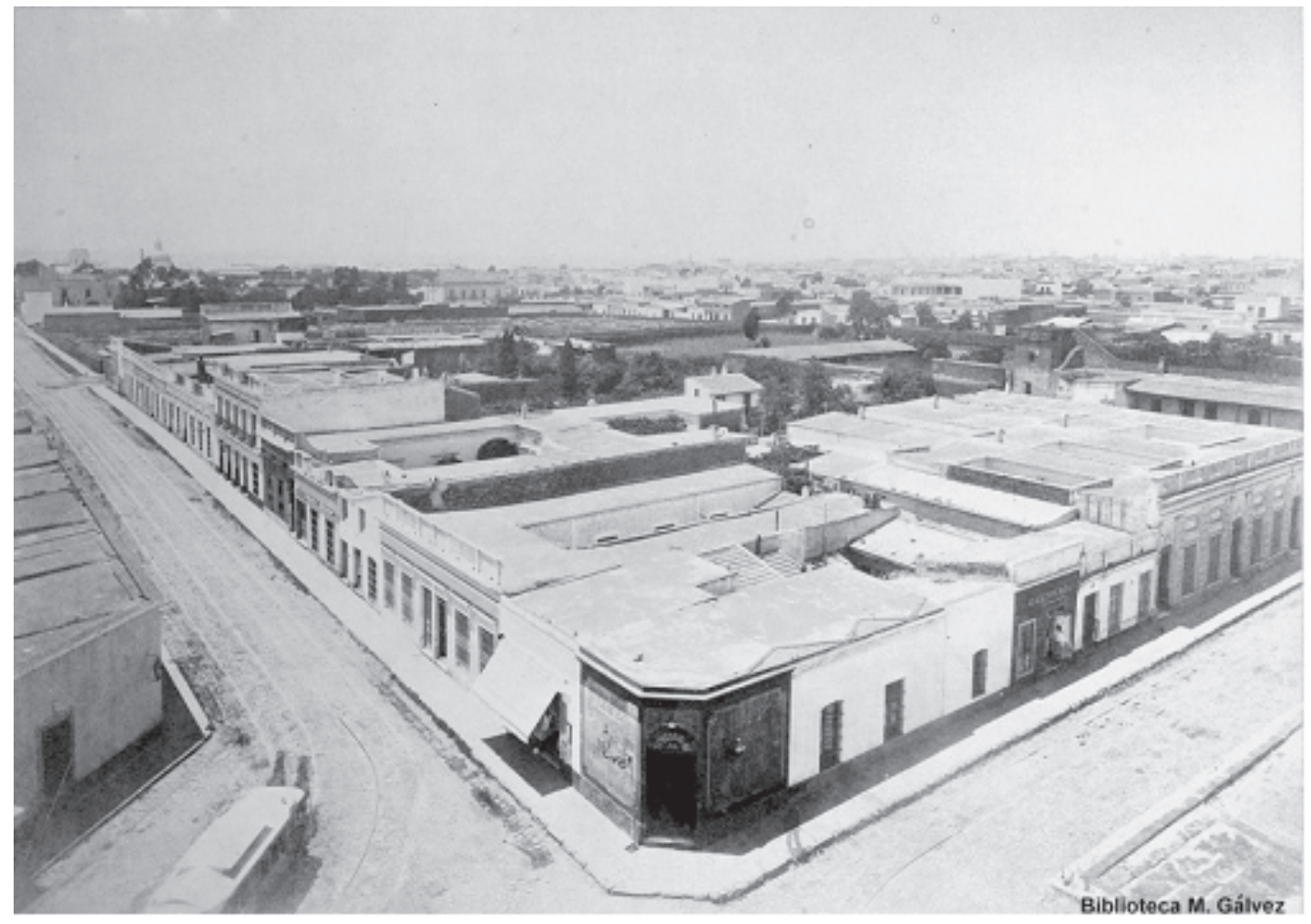

il. 1: Christiano Junior, "Buenos Aires (Vista panorámica)". En: Vistas y Costumbres de la República Argentina publicadas por Christiano Junior. Provincia de Buenos Aires, 1876.

Difícil es, dada la extensión sobre que se asienta esta populosa ciudad, ofrecer una vista que abrace un espacio suficiente para representarla. Tomada esta, desde uno de los mas altos puntos de mira, que se halla en condiciones de ser aprovechado por su posición, satisface en cierto modo, si bien nos compromete a presentar en la serie de estos álbums, otras láminas análogas que, así como la actual da una idea de la zona Sudeste, vista á vuelo de pájaro, las otras la darán de los extremos opuestos, completando así una vista general de la gran ciudad, que en 11 de junio de 1880, habranse cumplido tres centurias desde que se colocó en la esquina de la plaza Victoria, donde existe, la piedra angular de su fundación.

Al lado de este texto se encuentra una imagen donde se hacía bien visible la ortogonalidad característica de la ciudad a la vez que, tomada la fotografía desde una esquina, el damero cobraba dinamismo por las diagonales que fugaban desde el vértice. Un tranvía que empezaba a surcar la calle imprimía también movimiento a la escena. Este tipo de toma oblicua se presentaba con frecuencia en esta serie a la que Junior daba inicio con esta panorámica carente de edificios prominentes. Estos inmuebles serían el objeto de su cámara en las fotografías sucesivas. El fotógrafo realizaba este mismo tipo de acercamiento con una fotografía de la Plaza de la Victoria del primer álbum al advertir en el texto correspondiente que la Pirámide de Mayo y la Catedral -que se veían en la imagen- serían descritas en las respectivas láminas. Estas aparecían, recién, en el volumen siguiente. Respecto del texto que acompañaba a la imagen, cabe señalar que más que su 
extensión, lo que impedía abarcar la ciudad en una única toma era la falta de un punto de vista lo suficientemente elevado. La ciudad en la llanura ofrecía una dificultad para la composición. A la vez, si para un fotógrafo que venía de Rio de Janeiro la planicie debió ser especialmente llamativa, el escrito no daba cuenta de ello y, como ocurría con casi todos los otros textos, describía una idea de la ciudad más que lo visible fotografiado.

Ahora bien, ¿cuales eran los sitios elegidos por Junior para representar esa ciudad moderna? La Casa de Gobierno, la Catedral, el Congreso, las Plazas de la Victoria y 25 de Mayo, el Paseo de Julio, la ribera, las estaciones de ferrocarril: los motivos porteños se venían reiterando en las tomas de los diferentes fotógrafos. Se trataba de un recorrido iniciado en los años 50 por los primeros daguerrotipistas que realizaron vistas de la ciudad ${ }^{11}$, en los solares más antiguos y con sus edificios institucionales, que en la década del setenta y las posteriores seguían siendo los sitios más representativos y por lo tanto, fotografiados de Buenos Aires. ${ }^{12}$

Estos lugares especialmente connotados por su ubicación en el tejido urbano o por sus características o funciones políticas e institucionales y que fueron objeto, por esto, de la atención de los fotógrafos tanto viajeros como establecidos en el país, acrecentaron paulatinamente su carácter emblemático a partir de su reiterada reproducción en las fotografías. Un consenso sobre cuáles eran los sitios más destacados y luego su reconocimiento en las imágenes (la leyenda de anclaje aseguraba esto último) eran la clave para que esos espacios se constituyeran en iconografía representativa de la ciudad de Buenos Aires. En este sentido, la imagen fotográfica no sólo reduplicaba las características visuales de un sitio sino que retornaba sobre lo representado amplificando, también, su lugar prominente en el imaginario urbano; y luego siguiendo el círculo, la fotografía de ese lugar se volvía necesaria si se deseaba disponer de una colección de imágenes que diera cuenta de la ciudad.

Junior, como sus contemporáneos y quienes le seguirían, realizaba ese itinerario reforzando su poder evocativo en la configuración de un imaginario de la ciudad. Fotografiaba lo sólido, los edificios centrales que marcaban el carácter no sólo físico sino también institucional de Buenos Aires. Sin embargo, no todo era macizo en esa ciudad: entre la "gran aldea" y la Buenos Aires del Centenario existió un tiempo intermedio que Jorge Liernur ha visto como aquel de la ciudad

11 El primer daguerrotipista que realizó vistas de Buenos Aires y cuyo nombre se conoce es el estadounidense Charles DeForest Fiedricks. Se conservan en el Museo Histórico Nacional cuatro imágenes de su autoría y, de la misma época (1850 - 1855), otros cinco daguerrotipos cuyo autor no se conoce. Esas son las vistas más antiguas que se conservan de la ciudad de Buenos Aires. (Cf. Miguel Ángel Cuarterolo et al., 1995).

12 Dentro del género cabe mencionar para Europa el trabajo inaugural de los "viajes heliográficos" que distintos fotógrafos reunidos en la Société Héliographique Française (luego Photographique) Ilevaron a cabo por Francia entre 1850 y 1855 con el fin de realizar una colección de vistas, en soporte papel, de monumentos y sitios destacados. Por otra parte, como señala Boris Kossoy (2002) para el caso brasileño -haciéndolo extensivo a los demás países latinoamericanos- en la era de las cartes de visite no sólo la tecnología desarrollada en Europa y en Estados Unidos sino también los patrones estéticos fueron introducidos y aplicados por un número importante de fotógrafos extranjeros de modo que hubo una fuerte homogeneización tanto en la práctica como en la estética fotográfica. Natalia Majluf y Luis Eduardo Wuffarden (2001) apuntan en la misma dirección al referirse a la capital peruana: "Las imágenes de las capitales europeas, difundidas por el mercado turístico, habían servido como modelo formal." 
efímera, cuyos estratos se configuraban paralelamente a la formación de la ciudad moderna y sólida. Dice el autor respecto de las fotografías: "Siempre hemos aceptado, en su enunciado central de logros -la casa, el teatro, el monumento, el parque-, las imágenes que aquellos fotógrafos lanzaron hacia el futuro como los testimonios de la construcción del proyecto. Sin embargo, basta mirar los rasgos secundarios, transformar el fondo en figura, para advertir, allí donde la voluntad de representación se descuida, las elocuencias de esas huellas de la fugacidad" (LIERNUR, 1993, pp. 178-179). Entonces, la distancia entre las figuras y el fondo -tomando los términos de Liernur- es aquella existente entre lo habido y lo deseado: en ella puede proyectarse la mirada de los fotógrafos, las expectativas y el imaginario que pretendía dejarse asentado. Esa misma distancia concierne a un conflicto relativo al propio medio fotográfico: el que se da entre lo que la fotografía representa o revela -en tanto imagen que reproduce fielmente los rasgos visibles de la realidad- y aquello que construye.

Junior empleaba a veces las tomas oblicuas como la panorámica que abría el primer álbum. Ellas le daban la posibilidad de mostrar dos lados de un mismo edificio (como es el caso de la Administración de Rentas, la Casa Rosada, el Hospital Italiano o la Iglesia de Santa Felicitas) o los edificios prominentes sobre dos caras de una misma plaza (de la Victoria, por ejemplo, con el Cabildo y la Catedral). En esas plazas, los bancos estaban vacíos y exceptuando la Quinta del Alte. Brown delante de la que posaban varias personas y de las pequeñas siluetas a lo lejos o de las figuras vaporosas de los personajes móviles, pocas figuras dejaron su marca en las placas. Por lo general, los lugares fotografiados por el portugués para estos álbumes no se encontraban transitados por sus habitantes sino que se trataba de imágenes bastante despobladas en donde solían primar los espacios antes que sus usos ${ }^{13}$. Estas fotografías traducían una materialidad urbana en cierto modo vaciada de su funcionalidad. Eran espacios semi-vacíos que sin embargo, por las diagonales en las composiciones, no carecían de dinamismo. De esta manera, Junior lograba que la ciudad hablara casi por sí misma, estructuralmente, del potencial movimiento que contenía.

Si bien ambos formaban parte del título del álbum, el portugués privilegiaba claramente las vistas por sobre las costumbres. Sólo tres fotografías de las que llegaron a editarse se hacían eco de estas últimas. Pero por cierto que no consistían en hombres a caballo, mateando ni carneando vacas, sino otras nuevas, surgidas de un nuevo contexto. Escenas de la playa es el nombre de dos fotografías con poses muy compuestas, una de pescadores y otra de lavanderas en que los hombres regresaban portando las redes y las mujeres posaban en grupos,

13 Si bien por los tiempos de exposición los objetos móviles (como un transeúnte) salían borrosos, Junior ha optado en muchas ocasiones por incluir personas y/o teatralizar sus escenas. En este sentido, cabe señalar que esta ciudad de la que se muestra lo sólido (los espacios y edificios) no se repite de la misma manera en otras fotografías no incluidas en estos álbumes. En muchas de ellas se encuentran personas delante de los edificios o lugares (ej. Teatro Ópera, atr., ca. 1875, Portones de Palermo, atr., ca. 1874) y en otras, como se verá enseguida, la postura de la gente responde de manera absolutamente evidente a la solicitud del fotógrafo. Lo mismo cabe decir de otras ciudades. Paola Cortés-Rocca ha señalado en una sugestiva hipótesis que en estas fotos de Junior la ciudad estaría vacía de personas como marca de un espacio eminentemente institucional que debería convertirse en imagen de la nación. Agradezco a la autora el haberme facilitado una copia de su trabajo. 
respectivamente. Uno de estos epígrafes hacía, sugestivamente, referencia al movimiento y apuntaba a un aspecto propio de la vida urbana moderna: "Es un espectáculo interesante para el que pasea por las riberas del Plata, la vista multicolor y variada que presenta esta faja movible de mujeres de todas edades y países, entretenidas en el aseo de la ropa perteneciente á los 200.000 habitantes de esta gran ciudad."

La tercera imagen vinculada con las costumbres entre las veinticuatro de los álbumes es la única que tiene un personaje en primer plano.[il. 2]

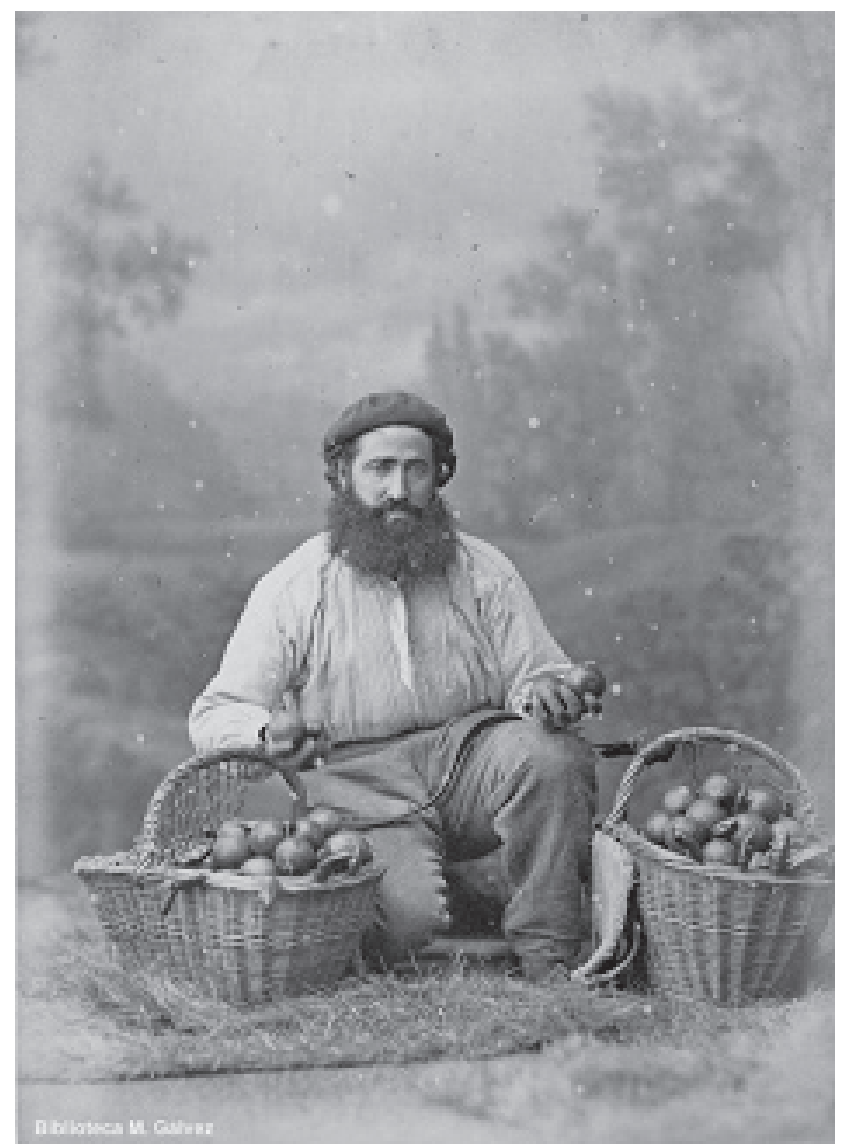

il. 2: Christiano Junior, "El naranjero". En: Vistas y Costumbres de la República Argentina publicadas por Christiano Junior. Provincia de Buenos Aires, 1877.

El texto que la acompaña es el siguiente:

El naranjero de la ciudad de Buenos Aires, es un hijo del progreso. Tipo sin precedente, ha surgido y tomado formas acabadas en medio del movimiento regenerador que en la República Argentina sucede á las viejas costumbres de la colonia. El oficio es ambulante; requiere vigor de pulmones para sostener el peso de dos grandes canastas, y buenas piernas para recorrer sendas cuadras gritando: arranca paraguaia! Con esta industria humilde, ejercida por inmigrantes italianos de la clase proletaria, se han levantado fortunas respetables, debidas, mas que á un lucro inmoderado, á la constante diligencia y hábitos económicos del naranjero. Cuando se ha cansado de esta vida, y la cosecha de patacones lo permite, deja las canastas y el gremio ambulante para abrir puesto en un mercado de abasto, donde su nueva categoría le permite una existencia mas sedentaria. 
Su condición de inmigrante es lo que hacía de este personaje que circulaba vociferando por la ciudad un individuo de su tiempo. Si "sucede a las viejas costumbres de la colonia" es porque ya no se trataba aquí de un vendedor negro o mestizo como aquellos representados en los Trajes y costumbres de Buenos Aires de César Hipólito Bacle, por ejemplo, sino de un italiano que, al gritar en cocoliche, con sólo ofrecer sus naranjas evidenciaba su origen. De retomar la nomenclatura iconográfica decimonónica de los tipos y costumbres, cabe distinguir que aquí no es nueva la costumbre (la venta ambulante) sino el tipo que la lleva adelante: un "hijo del progreso" que desarrolla una actividad por la que ahora, en un contexto socio económico de progreso, puede aspirar al suyo propio.

Pero curiosamente, mientras tanto las lavanderas como los pescadores fueron tomados en sus lugares de trabajo, este hombre de oficio ambulante fue sacado de las calles para posar en estudio. Hay algunas consideraciones sobre este punto. Por un lado, bien es cierto que los telones que representaban paisajes eran, junto con los que recreaban interiores burgueses (con columnas, cortinas y escaleras), los fondos habituales de los retratos de la época y que no había, en cambio, representaciones de las calles en ellos. En caso de ser el escogido ese espacio no se escenificaba sino que el fotógrafo trasladaba su equipo a exteriores y trabajaba con la ciudad misma como fondo. Pero, además, cabe notar que si bien Junior fue el primero en sacar tipos populares tanto en estudio como en exteriores (ALEXANDER-PRIAMo, 2002, p. 39), en esta ocasión no sólo no sacó sus aparatos a la calle, sino que tampoco escogió un fondo neutro como los que empleara para otros oficios urbanos como los Vendedor de diarios o el Vendedor de aves y pescados. ${ }^{14}$ En cambio, el fondo delante del cual se encontraba en cuclillas su personaje eminentemente urbano, este hijo del progreso, no respondía a su contexto sino que, con los árboles difusos detrás, tenía un fuerte tono agreste, con ciertas reminiscencias románticas incluso. ${ }^{15} \mathrm{En}$ un sentido contrario a sus palabras preliminares y al grueso de su obra, poco hay menos inequívoco como signo del progreso que esta imagen del naranjero. Si el texto encontraba en este hombre un sucesor de las viejas costumbres coloniales, la imagen, por su lado, cargaba con la tradición y aunque representara un nuevo tipo, estéticamente mantenía lazos con aquellos que lo precedieron.

Mención aparte merece la fotografía de la Boca del Riachuelo. Ni vista ni costumbre, los mástiles de los barcos y las casas de madera enmarcan a un gran número de individuos (hombres en su gran mayoría) que se congregaron ante la cámara de Junior. El texto decía de esta zona "unida a la capital por una línea de ferrocarril y otra de tranvía, [que] forma uno de sus arrabales, y es susceptible de un gran

14 Fotografías atribuidas, cf. Alexander y Priamo, op. cit. En Vendedor de diarios (ca. 1875) existe una franca contraposición entre el espacio y la situación del retratado: en un fondo perfectamente neutro un joven con diarios bajo el brazo derecho sostiene la mano izquierda al costado de su boca, en claro gesto de orientar su voz al ofrecer el periódico. Así, la teatralización del personaje no se continúa en el escenario en que se desarrolla la acción.

15 Es interesante notar también que ese mismo fondo fue empleado en otras oportunidades tanto para personajes citadinos como rurales (para un peón de campo y un aguatero, por ejemplo). Otra fotografía de este naranjero lo ubica de pie en el mismo escenario (en Archivo General de la Nación). 
porvenir" que en ella se agitaba "una importante población, donde predomina la colonia italiana". Los márgenes de la ciudad y los inmigrantes son objeto de esta imagen. Eso es lo nuevo y es también el progreso. Si la representación puede dejar dudas de este progreso (o, más bien, de su signo netamente positivo), una vez más el texto atajaba y anclaba el sentido: se trataba de un arrabal susceptible de un gran porvenir augurado por las buenas comunicaciones con el centro de Buenos Aires.

En las fotografías que componen los dos álbumes de Junior los habitantes (exceptuando los trabajadores y los inmigrantes) y los espacios de organización institucional apenas se cruzaban. El fotógrafo escogió días y horarios en que hubiera poco movimiento en el centro de la ciudad. Lo circunstancial (transeúntes, carruajes, personas descansando en un banco, etc.) desaparecía de las tomas dirigidas a los edificios institucionales que, con su solidez material, debían contribuir a generar la idea de estabilidad política. Por su parte, los trabajadores eran casi los únicos habitantes visibles y actuaban en otras zonas urbanas, en las costas del río (o en el estudio de Junior).

En este y varios sentidos, la fotografía correspondiente al Puente del Ferrocarril a la Ensenada resulta un caso particularmente interesante. Se trata de una vista intervenida por la señalización de un trabajo/oficio: el carro-laboratorio del mismo Junior, identificable por la inscripción sobre sus lados, representa su profesión y remite también a la realización de esta fotografía en particular . [il. 3]

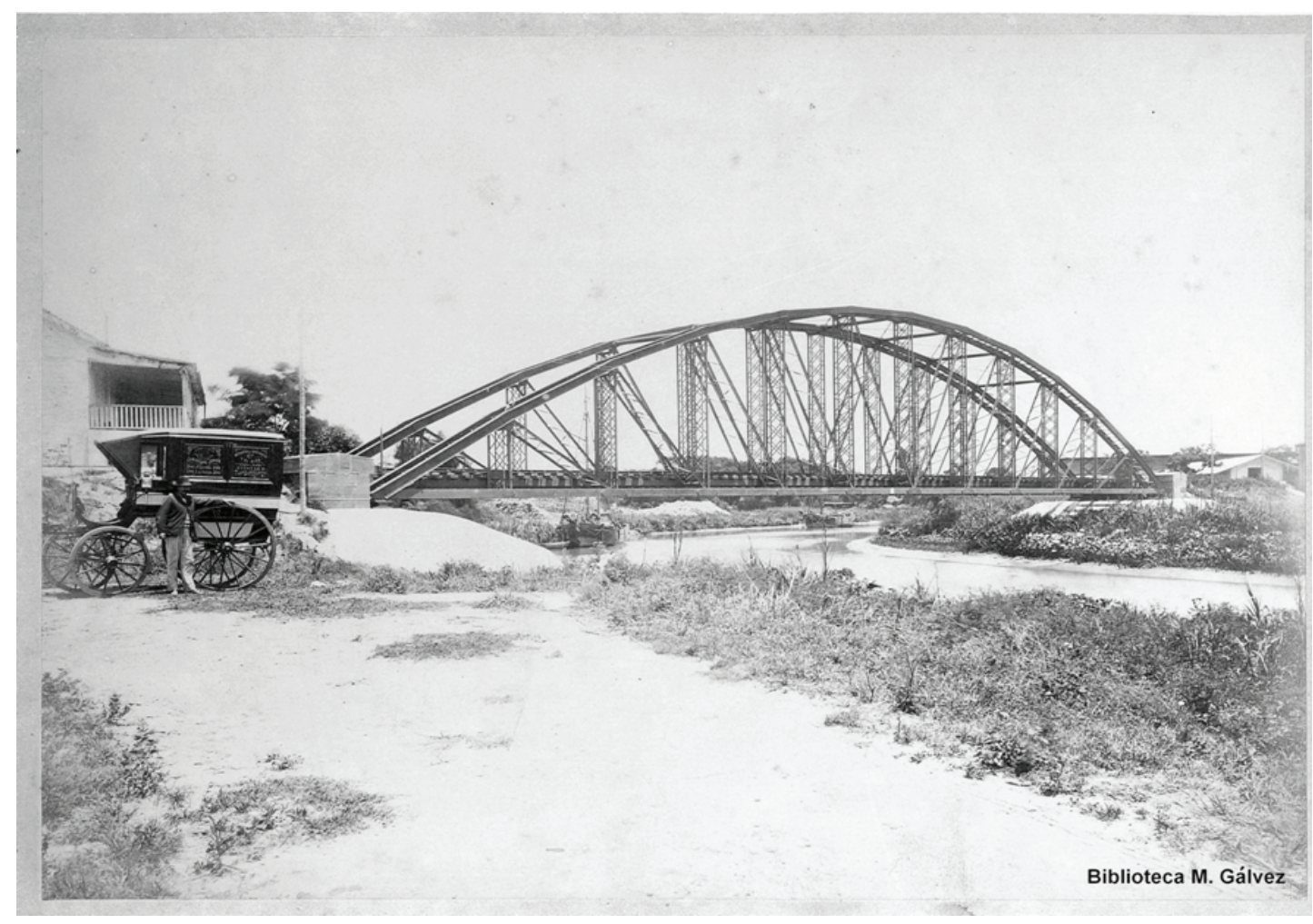

il. 3: Christiano Junior "Puente del Ferrocarril a la Ensenada". En: Vistas y Costumbres de la República Argentina publicadas por Christiano Junior. Provincia de Buenos Aires, 1877. 
A partir de esta imagen bisagra cabe pasar del análisis del modo en que las fotografías y el prólogo exponían la intencionalidad del trabajo de Junior (mostrar el progreso, difundir los adelantos y las bellezas nacionales en el país y en el exterior, traducir en imágenes la fortaleza de las instituciones) y considerar, en lo que sigue, la posición del fotógrafo como autor de sus álbumes. Con las formas y posibilidades que son propias de cada medio, tanto las palabras de Junior como sus imágenes se hicieron eco también de algunos aspectos de la realización de su proyecto fotográfico.

He separado un fragmento del prólogo del primer álbum para poder analizarlo a la luz de cuestiones referidas al trabajo y la posición del fotógrafo:

Esta empresa es ardua, lo comprendo, ella exige mucha constancia, empleo de ingente capital, y sobre todo, gran pericia y buen deseo en los diversos colaboradores, para que su resultado responda á mis esperanzas y sacrificios.

Empero, librada aquella parte de trabajo que no es posible ejecutar personalmente, á caballeros á quienes un interés análogo ó el acendrado patriotismo, impulsa en su cooperación, tengo fe en el resultado de este que llamaré mi campaña artística en el Río de la Plata.

[...]

Por ahora, la parte descriptiva de las vistas, está confiada á los señores Carranza y Pelliza y de cuyo mérito juzgaran los que se dignen favorecer nuestra publicación; previendo desde luego, que empleados de la casa con elementos de primer orden, recorren esta Capital y Provincias, á fin de que los negativos sacados del natural, permitan sin interrupción el desenvolvimiento gradual y metódico de la idea que me agita. ${ }^{16}$

Interesa por un lado llamar la atención sobre el señalamiento sobre estas imágenes "sacadas del natural". Una de las dos vertientes más importantes en la fotografía comercial consistía en las vistas, de ahí que los estudios cuidaran su producción frente a sus competidores. Existía ciertamente un tema económico en la no mediación entre la cámara y el objeto o paisaje a fotografiar por el costo de los equipos y los viajes hasta los distintos sitios. Una cuestión de tiempo, marcada por la conveniencia en satisfacer inmediatamente la creciente demanda de imágenes de diferentes lugares, podía además incentivar la venta de fotografías ajenas. En este sentido, al igual que otros fotógrafos contemporáneos, Junior protegía sus intereses: al inicio de su álbum una breve frase se recortaba en una hoja en blanco: "El propietario se reserva el derecho de reimpresión, y perseguirá ante los Tribunales al que la haga sin su consentimiento". Pero en el caso de Junior parece añadirse para esta protección una concepción particular sobre su trabajo, una idea de obra personal: lo que Junior quería proteger era el provecho económico de la "idea que lo agitaba". La idea parecía distinguirse claramente de la realización efectiva, puesto que, según afirmaba, empleados de su casa fotográfica se harían cargo de tomar esas fotografías. Volvía sobre ello: 
Empero, librada aquella parte de trabajo que no es posible ejecutar personalmente, a caballeros a quienes un interés análogo o el acendrado patriotismo, impulsa en su cooperación, tengo fe en el resultado de este que llamaré mi campaña artística en el Río de la Plata.

Una campaña artística, una idea que lo agitaba: todo término comercial o de lucro cedía en estas líneas para dar paso a una perspectiva creativa y personal en un vocabulario con ciertas reminiscencias románticas incluso. El registro fotográfico del natural era fruto de la idea de Junior antes que de la acción concreta del empleado de la casa. La experiencia de estar allí, ver el espacio, seleccionar el fragmento parecía tener menos trascendencia que la concepción y el desarrollo del proyecto en su totalidad. En este sentido cabe establecer una distinción, por ejemplo, con Samuel Boote quien a fines de la década del '80 anunciaba en la tarjeta promocional que pegaba en sus álbumes "A pedido se envía un fotógrafo a cualquier parte". Allí, por supuesto, no había posibilidad de inscripción de una idea como la que "agitaba" a Junior; se trataba exclusivamente de la ejecución del encargo de un particular por parte de un operario.

Esto es muy distinto entonces a lo que ocurría con los álbumes que el portugués entendía como su campaña artística. Si el hecho de que otros hicieran las fotografías no implicaba necesariamente un menor grado de idea y realización individual, mucho menos debían hacerlo los textos. Carente de un perfecto manejo del idioma y de la historia de la Argentina, Junior los había dejado en manos de Carranza y Pelliza. Es interesante en este punto retornar sobre el par textoimagen de El naranjero pues, como ya fue señalado, hay una fuerte disonancia entre ambos: resonancias costumbristas en la imagen donde un hombre ofrecía sus frutos delante de un fondo de paisaje y un texto que lo situaba como personaje eminentemente urbano. El autor de la imagen y los autores del texto fueron allí en distinta dirección y curiosamente, el que iba rezagado en el tiempo -según el espacio en que actuaba este vendedor- era Junior.

Ahora bien, volvamos a la parte del prólogo en la que Junior dejaba ver que la idea y el proyecto global estaban por encima de la realización efectiva de las fotografías para apuntar que esa concepción fue muy pronto abandonada. Las imágenes que sus empleados le traían debieron dejarlo disconforme, posiblemente no por la calidad sino porque no había sido él quien había tomado todas las decisiones de seleccionar, recortar, componer, etc. En efecto, según exponía años más tarde en sus anuncios de los álbumes "he venido a convencerme de que por mejor que fuera la elección de esa persona [el fotógrafo], sería imposible que ella pudiera comprender mis ideas artísticas." ${ }^{17}$ En 1879 comenzó su "viaje artístico" -según sus propias palabras- por las provincias para continuar el trabajo iniciado en la de Buenos Aires y confeccionar los álbumes respectivos que, finalmente, nunca 
vieron la luz ${ }^{18}$. Había que estar en cada lugar: cobraba peso el hecho de recorrer sitios y seleccionar fragmentos, el atravesar la experiencia de detenerse frente al espacio del que se tomarían vistas del natural y, sobre todo, el componer las escenas según sus propios criterios.

En muchas imágenes de Junior se percibe muy claramente su haber estado allí. No me refiero solamente a la fotografía del Puente del Ferrocarril a la Ensenada donde se ve su carreta con la inscripción de su estudio -lo cual funcionaba como forma publicitaria y como firma- sino a otras imágenes en que es muy fuerte la presencia de quien no estaba delante de la cámara.

Los tiempos de exposición para la obtención de una fotografía nítida forzaba a quienes fueran a ser fotografiados a unos instantes de quietud, de lo contrario se veían los cuerpos con menor consistencia y definición o directamente movidos. Pero aparte del tiempo de exposición, hacían falta antes varios minutos para preparar la cámara y la toma: disponerla sobre el trípode, elegir el punto de vista, colocar la placa, etc., una cantidad de tareas que no pasaban desapercibidas a quienes estaban cerca. Lejos de la toma sorpresiva, todos estaban al tanto de que iba a hacerse una fotografía y de aquí las tan frecuentes miradas a cámara, los altos en las actividades y las poses que se encuentran en las imágenes del período.

Ciertas fotografías de Junior hacen más claro esto, pues tornaron casi "visible" la operación fotográfica al llevar al extremo esta detención de gestos y poses convirtiéndolas en formas claramente pautadas. Es el caso, entre muchos otros, de una fotografía de la estación de Chas [il. 4] en la que prácticamente todas las personas que se encontraban allí miran a un punto incierto ubicado a la izquierda de la imagen poniendo en evidencia la artificiosidad de la escena.

18 Aunque no lo terminara, su proyecto de sacar vistas de los lugares más destacados de toda la República no tenía precedentes. De todas formas, según registros hubo al menos una colección completa de las Vistas y costumbres que contenía 500 imágenes -si bien sin fotos de las provincias del litoral ni las leyendas de cada una- que fue entregada por Junior a la Corporación Municipal de Tucumán por su suscripción previa. Cf. Alexander y Priamo, 2002, p. 32. 


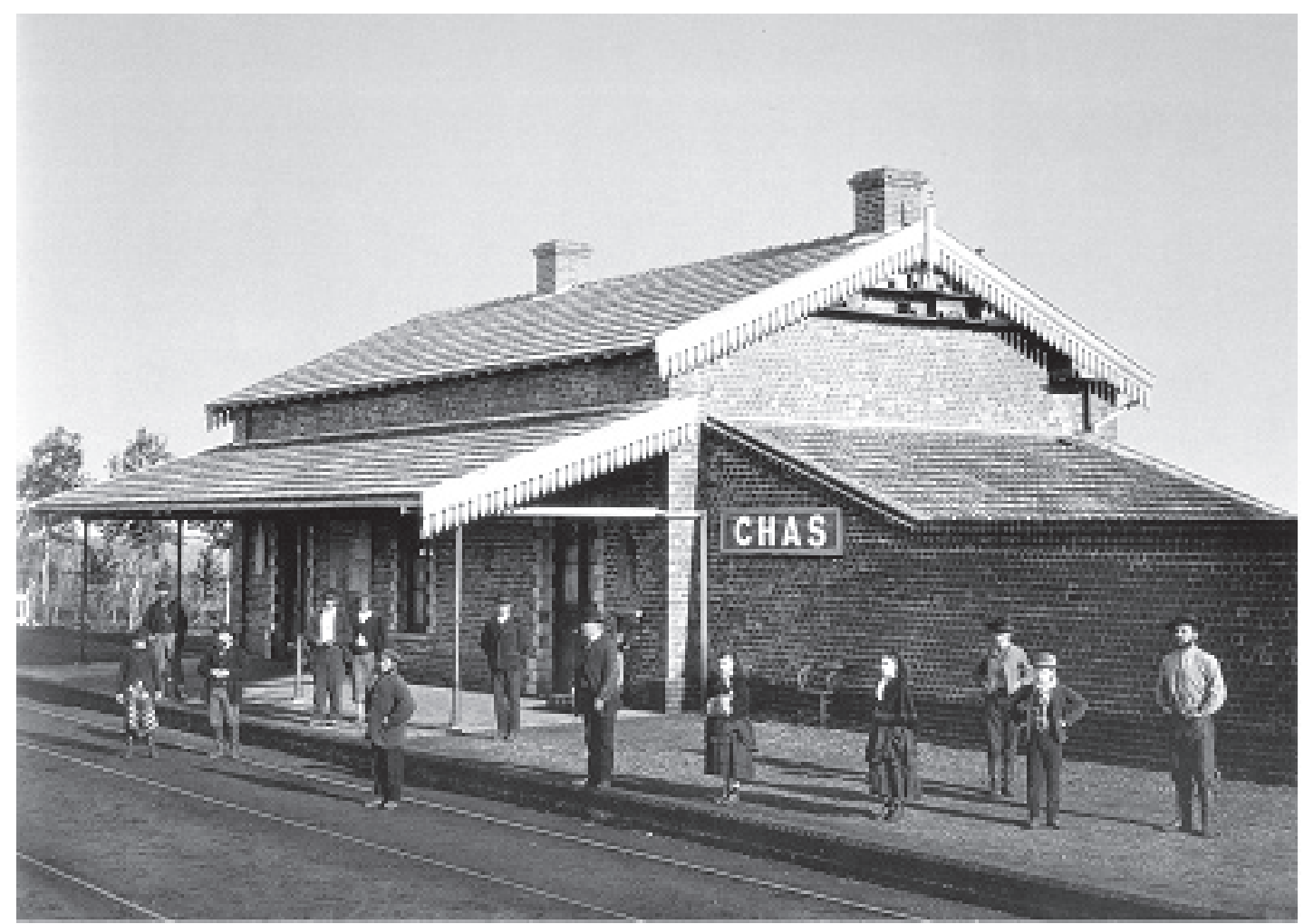

Il. 4: Estación Chas del Ferrocarril del Sud, atribuida, ca. 1875.

Detenidamente compuesta, se apuntó a evitar en este caso las miradas y poses hacia la cámara observables, por ejemplo, en la ya mencionada fotografía de las lavanderas en el álbum de 1877. El efecto, mucho más teatral, exhorta a una búsqueda más allá de los límites de la imagen y, lo que es más interesante, no hacia la izquierda -no hacia el punto al que estos personajes dirigen sus miradassino hacia el lugar en que estaba Junior o, mejor, hacia Junior mismo, es decir, al sitio de donde provino la indicación, el artificio, la construcción de la representación como tal. Otras imágenes hacen particularmente visible esta forma de trabajo de Junior: se trata de dos fotografías de un seminario en la Provincia de San Juan tomadas en 1880 [ils. 5 y 6 ]. 

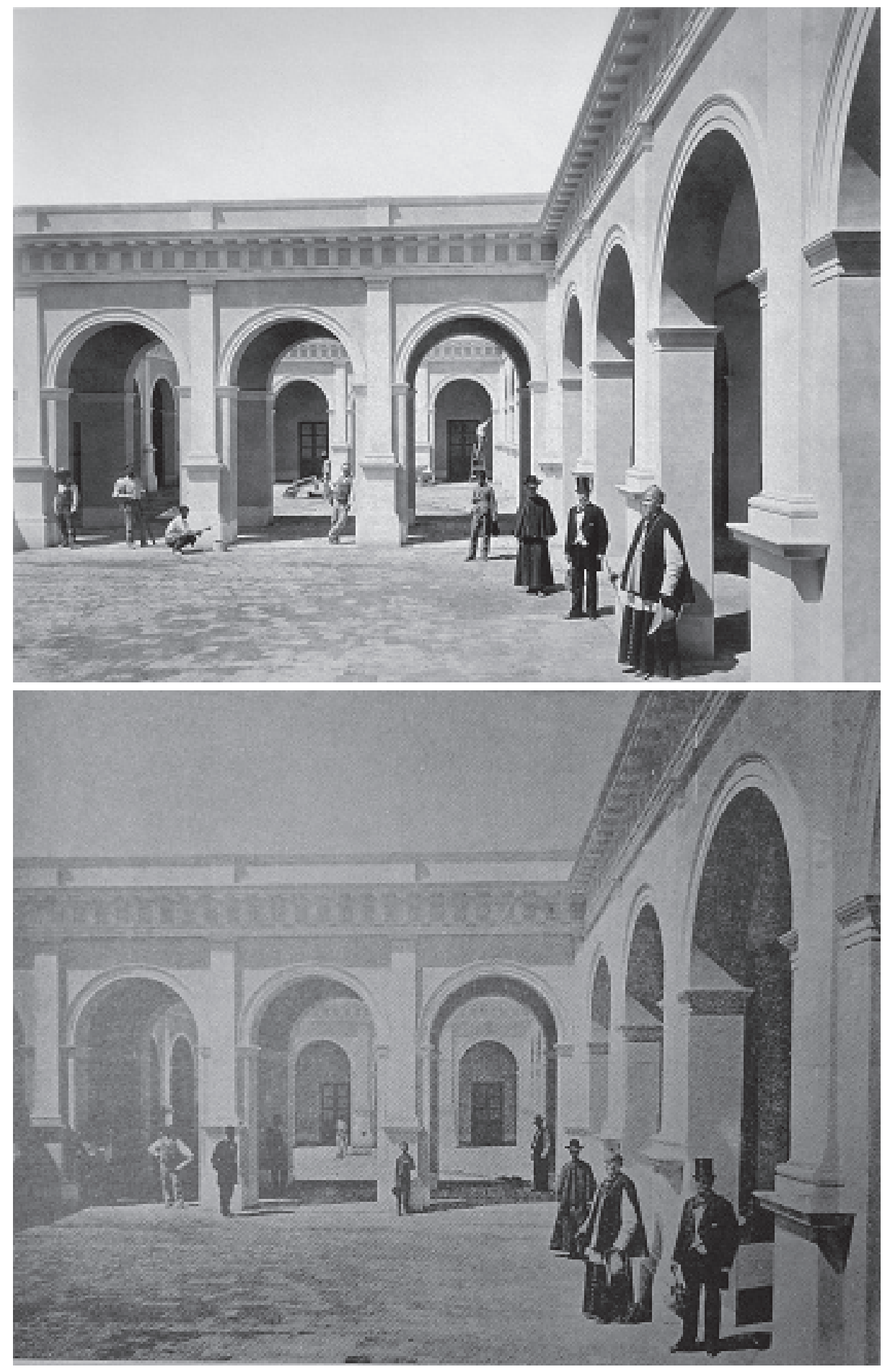

ils. 5 y 6: Christiano Junior, Seminario. Provincia de San Juan, $1880^{19}$.

Varios personajes se ubican en una composición que aprovecha la rica perspectiva de unas arcadas vistas frontalmente y otras en escorzo. Los hombres del plano más lejano trabajan o, más bien, simulan continuar con sus actividades (algunos pintan, otros cargan una carreta). Los más próximos, en cambio, congelaron todo

19 Una de ellas fue reproducida en La Ilustración Sudamericana, 16 de noviembre de 1894 . Ni en el pie de foto ni en el apartado "Nuestros grabados" -donde se describen temáticamente las reproducciones- se menciona el nombre del autor. La otra imagen ha sido recientemente reproducida en Un País en transición. Fotografías de Buenos Aires, Cuyo y el Noroeste, op. cit., p. 83. 
movimiento para la cámara de Junior y los tres que se encuentran más cerca aun -dos religiosos y un individuo de levita- están, de manera absolutamente evidente, respondiendo a una pose señalada. Lo interesante es confrontar esta imagen con otra en la que se perciben algunos cambios en los hombres de detrás -hay alguno de más o de menos, sus posturas varían-. Por su parte, los de primer plano mantienen exactas sus posturas modificando, en cambio, su posición relativa en la escena. Allí donde estaba el fraile más obeso ahora se ubica el hombre de levita pero, por lo demás, ambos están en idéntica posición corporal que en la imagen anterior. En estas y otras imágenes se percibe claramente al autor y, allí, el modo en que se convertía en autoridad en tanto disponía las posturas y ubicaciones de quienes aparecerían en las fotografías, una autoridad que regulaba, por unos minutos, las conductas de otros y comandaba una puesta en escena.

En tanto se descubre la orquestación, la imagen reenvía al otro lado de la cámara, a los hilos invisibles que la compusieron, a su autor. De ahí, por la medida de la intervención de Junior se comprende que en 1879, dos años después de explicar que sus empleados harían las vistas, tomara todo el trabajo fotográfico a su cargo recorriendo las provincias. Estas fotografías tomadas en San Juan de 1880 son claro ejemplo de cómo, en oposición a lo que parecía al inicio, no le bastaba la idea para hacer de sus álbumes un proyecto artístico individual. En la realización efectiva de las fotografías Junior no sólo seleccionaba y operaba con lo existente sino que lo ordenaba dejando de este modo una muy fuerte impronta personal en las imágenes que, por ello, remiten al autor y revelan, también, aquello que tienen de construcción. Como hemos visto, esta construcción -el relato de Juniorestuvo marcada por la voluntad de mostrar el progreso al cual el arte, a criterio de muchos de sus artífices, estaba sirviendo. En efecto, en el prólogo de su segundo álbum y luego de ganar una medalla en la exposición anual de la Sociedad Científica Argentina el fotógrafo sostenía: "Estas recompensas nos alientan en la difícil carrera del arte, pues forman ellas el laurel simbólico con que la civilización galardona á los obreros del progreso." (JUNIOR, 1877)

Estas palabras dejan nuevamente al descubierto una doble mirada de Junior: aquella que tenía sobre el tiempo y el lugar en que le tocó vivir y que marcó fuertemente las elecciones sobre lo que fotografiaba, sus recortes, lo incluido y lo excluido para difundirse y perdurar en imagen y, también, la imagen de sí mismo, la que construyó a la par de su obra. Esta última, finalmente, nos permite no sólo acercarnos a la consideración que como profesional tenía Junior de sí mismo, sino que puede ayudarnos a vislumbrar, también, su inscripción en la escena fotográfica local y ciertos delineamientos en torno a la figuras del autor o el precursor de un proyecto fotográfico en el Buenos Aires de fin de siglo.

NOTA: Las ilustraciones 1, 2 y 3 fueron reproducidas de las existentes en la Biblioteca Manuel Gálvez. La 4 y 5, del Archivo Gráfico de la Nación, Argentina. 


\section{Referencias y bibliografía:}

AA.VV . Roland Barthes et la photo: le pire des signes. Les Cahiers de la photographie (hors série). ACCP, 1990.

ALEXANDER, Abel. "El gran fotógrafo Christiano Junior en Mendoza". In: Historia de la fotografía. Memoria del $2^{\circ}$ Congreso de Historia de la Fotografía en la Argentina. Buenos Aires: Comité Ejecutivo Permanente, 1993.

"Christiano Junior, fotógrafo pionero de la Sociedad Rural Argentina"

In: www.geocities.com/abelalexander/chjunior.htm

"Christiano Junior en Quilmes". In: www.geocities.com/ abelalexander/chjunior4.htm.

ALEXANDER, Abel y Luis Priamo. "Dos pioneros del documentalismo fotográfico". In: Buenos Aires. Ciudad y campaña, 1860-1870. Fotografías de Esteban Gonnet, Benito Panunzi y otros. Buenos Aires: Fundación Antorchas, 2000, pp. 23-35.

ALEXANDER, Abel y Luis Priamo. "Recordando a Christiano". In: Un País en transición. Fotografías de Buenos Aires, Cuyo y el Noroeste, Christiano Junior, 1867-1883. Buenos Aires: Antorchas, 2002.

ALTAMIRANO, Carlos y Beatriz Sarlo, Ensayos argentinos. De Sarmiento a la vanguardia. Buenos Aires, Ariel, 1997.

CORTÉS ROCCA, PAOLA. Vistas de fin de siglo: ficciones nacionales, paisajes y multitudes. Tesis de doctorado, Princeton University, inédito (Seeley G. Mudd Library), 2005.

CUARTEROLO, Miguel Ángel et al. Los años del daguerrotipo. Primeras fotografías argentinas. 1843-1870. Buenos Aires: Fundación Antorchas, 1995.

JUNIOR, Christiano. Vistas y Costumbres de la República Argentina publicadas por Christiano Junior. Provincia de Buenos Aires. 1876.

Vistas y Costumbres de la República Argentina publicadas por Christiano Junior. Provincia de Buenos Aires. 1877.

KOSSOY, Boris. Dicionário Histórico-Fotográfico Brasileiro. Fotógrafos e Ofício da Fotografia no Brasil (1833-1910). São Paulo: Instituto Moreira Salles, 2002. HORA, Roy. Los terratenientes de la pampa argentina. Una historia social y política. 1860-1945. Buenos Aires: Siglo Veintiuno, 2002.

LIERNUR, Jorge Francisco. "La ciudad efímera". In: Jorge F. Liernur y Graciela Silvestri, El umbral de la metrópolis. Transformaciones técnicas y cultura en la modernización de Buenos Aires (1870-1930). Buenos Aires: Sudamericana, 1993.

MAJLUF, Natalia y Luis Eduardo Wuffarden. "El primer siglo de la fotografía, Perú 1842-1942.". In: La recuperación de la memoria. Perú 1842-1942. Lima: Fundación Telefónica y Museo de Arte de Lima, 2001.

PRIAMO, Luis. "Benito Panunzi, Antonio Pozzo y otros fotógrafos italianos del siglo pasado en la Argentina". In: AA.VV. Las artes y la arquitectura italiana en la Argentina. Siglos XVIII y XIX. Buenos Aires: Fundación Proa, 1998.

ZEBEIRO, Blanca. "Un mundo rural en cambio". In: Bonaudo, Marta (dir.), 
Liberalismo, estado y orden burgués, Nueva Historia Argentina, Tomo IV. Buenos Aires: Sudamericana, 1999.

\begin{abstract}
:
The present essay analyses some aspects of the work by Christiano Junior in Argentina, particularly in the city and the state of Buenos Aires in the late 1870s, following two lines of analysis. On the one hand this essay aims at linking Christiano Junior's work to the idea of progress that pervades the end of that century, the entrepreneurship, the mentalities and accounts (including photography). On the other, Junior's work is analyzed from the perspective of the idea tout court, as it seems to concentrate the image of the photographer over himself in relation to his activity and production.
\end{abstract}

\title{
Key words:
}

Photography, progress, author, nineteenth century, Argentina.

Recebido em 10/05/2009. Aprovado em 08/06/2009. 